\title{
Electrophoretic detection of proteases from different Flexibacter columnaris strains and assessment of their variability
}

\author{
J. M. Bertolini ${ }^{1}$, J. S. Rohovec ${ }^{2, *}$ \\ ${ }^{1}$ Laboratory for Fish Disease Research, Department of Microbiology, Oregon State University, Hatfield Marine Science Center, \\ 2030 S. Marine Science Dr., Newport, Oregon 97365-0138, USA \\ ${ }^{2}$ Laboratory for Fish Disease Research, Department of Microbiology, Oregon State University, Corvallis, Oregon 97331-3804, \\ USA
}

\begin{abstract}
Proteases with apparent molecular weights of 47,40,34 and $32 \mathrm{kD}$ were identified in cellfree extracellular products (ECP) of Flexibacter columnaris by using substrate SDS-polyacrylamide gel electrophoresis. Similar protease profiles were associated with ECP collected at intervals during several days in culture. Furthermore, the proteases produced by a collection of $13 \mathrm{~F}$. columnaris isolates from a variety of fish species and geographic sources showed great uniformity but differed markedly from the protease profiles of 7 other gliding bacteria examined. The $13 F$. columnanis isolates degraded gelatin, casein, hemoglobin, fibrinogen and elastin. Results of experiments with protease inhibitors indicated that zinc metalloproteases constitute a major component of the extracellular proteases of $F$. columnaris.
\end{abstract}

\section{INTRODUCTION}

Columnaris disease, caused by the bacterium Flexibacter columnaris, was first described by Davis (1922); however, the name of the organism was only recently validated (Bernardet \& Grimont 1989). The disease causes losses in a wide variety of cultured (Fish \& Rucker 1943, Wakabayashi et al. 1970, Bootsma \& Clerx 1976, Amin et al. 1988) and feral (Davis 1947 , Wobeser \& Atton 1973, Becker \& Fujihara 1978) freshwater fishes. One common characteristic of the disease is pronounced erosion or necrosis of external tissues, with the gills often being the major site of damage (Davis 1922, 1947, Fish \& Rucker 1943, Pacha \& Ordal 1967, Wood 1974, Farkas \& Olah 1986). This observation, coupled with the observation of proteolytic activity by F. columnaris in vitro (Pacha $\&$ Porter 1968, Song et al. 1988, Bernardet 1989), suggests that the production of extracellular proteases may be an important virulence mechanism for the bacterium.

Recently there has been much research directed toward the characterization of bacterial and fungal proteases and their role in the pathogenesis of disease in mammals (Holder 1985, Bejarno et al. 1989, Azghani et al. 1990, Rhodes et al. 1990), fish (Hastings \& Ellis 1985, Fyfe et al. 1987, Kanemori et al. 1987, Rockey et

\footnotetext{
- Addressee for correspondence
}

(c) Inter-Research/Printed in Germany al. 1988, Norqvist et al. 1990, Chabot \& Thune 1991, Nieto \& Ellis 1991) and shellfish (Nottage \& Birkbeck 1987). In many instances, these proteases have been implicated as important virulence factors. Those fish and shellfish pathogens which have been studied are all within the Vibrionaceae (Aeromonas and Vibrio spp.); however, the importance of the proteases of the gliding bacteria has received little attention. An understanding of Flexibacter columnaris proteases is needed in order to investigate the role of these enzymes in pathogenicity.

In the present study we identified extracellular proteases produced by Flexibacter columnaris, assessed variations in protease production which occur as a factor of culture age, and examined the variability in protease production among a collection of $F$. columnaris isolates. The identification of major, common, extracellular proteases will help to focus future studies on proteases which appear most likely to be important virulence factors. We also wished to identify methods, conditions, and strains that would be useful in producing proteases for additional studies.

\section{MATERIALS AND METHODS}

Bacterial isolates. Thirteen Flexibacter columnaris isolates were included in the study (Table 1). The 
Table 1. Sources of the Flexibacter columnaris isolates used in this study. All Flexibacter columnaris isolates, except 2.19, were included in a comparison of biochemical and biophysical characteristics of isolates associated with columnaris disease (Song et al. 1988) and are part of the Oregon State University Fish Disease Laboratory culture collection. Isolate 2.19 was contributed by J. P. Hawke, Louisiana State University, Baton Rouge, LA, USA

\begin{tabular}{|llllc|}
\hline $\begin{array}{l}\text { Isolate } \\
\text { no. }\end{array}$ & Designation & Location & \multicolumn{1}{c}{ Host } & $\begin{array}{c}\text { Year } \\
\text { isolated }\end{array}$ \\
\hline 2.1 & & & Oncorhynchus tshawytscha & 1969 \\
2.2 & DD3-69 & OR & Salmonid fish & $1957-1959$ \\
2.3 & 234 & WA & O. tshawytscha & 1980 \\
2.6 & RO-4-80 & OR & Carassius auratus & 1978 \\
2.7 & T13 & Japan & Ictalurus punctatus & 1969 \\
2.8 & IC8m & ID & Salmonid fish & $1957-1959$ \\
2.9 & 238 & WA & Salmonid fish & $1957-1959$ \\
2.10 & $244 \mathrm{r}$ & OR & M. kisutch & 1968 \\
2.11 & BH2 & OR & Catostomus macrochellus & 1980 \\
2.12 & Rogue No. 9 & OR & O. kisutch & 1983 \\
2.13 & K4I & OR & C. auratus & 1983 \\
2.15 & RC & GA & I. punctatus & 1984 \\
2.19 & GA505 & LA & & 1990 \\
\hline
\end{tabular}

bacteria were routinely cultured at $25^{\circ} \mathrm{C}$ using tryptone yeast extract plus salts (TYES) medium (Holt 1988). All isolates were prepared for long-term storage at the beginning of the study by culturing for $72 \mathrm{~h}$ in TYES medium containing $0.18 \%$ agar, homogenizing the culture thoroughly with a pipet, and then freezing aliquots of the suspension at $-70^{\circ} \mathrm{C}$.

Other gliding bacteria isolates in this study included: Cytophaga succinicans; Cytophaga johnsonae UW101; and Flexibacter aurantiacus ssp. excathedrus ATCC 23086. Flexibacter psychrophilus NCMB 1947 was cultured at $18^{\circ} \mathrm{C}$. An isolate of Cytophaga sp., designated SF86-37, from a disease outbreak in seawater pen-reared Atlantic salmon Salmo salar, similar to the isolate described by Kent et al. (1988), and 2 Cytophaga sp. isolates, designated C1B2 and WB1B1, from the Pacific oyster Crassostrea gigas (Dungan et al. 1989) were cultured at $18^{\circ} \mathrm{C}$ in Cytophaga agar (Anacker \& Ordal 1959) prepared with $70 \%$ seawater (SWCA). These isolates were supplied by C. F. Dungan, Cooperative Oxford Laboratory, Oxford, MD, USA.

Bacterial extracellular products preparation. Extracellular products were prepared by methods described by Allan \& Stevenson (1981). Dialysis tubing (Spectra/Por 2, Spectrum Medical Industries, Inc.) was cut into disks and autoclaved. The sterile disks were aseptically applied to the surface of TYES agar plates or to SWCA plates for marine bacteria. The plates were inoculated with $0.2 \mathrm{ml}$ of broth culture which was spread over the surface of the membrane with a sterile bent glass rod. The dialysis membrane overlay extracellular products (DMO-ECP) were harvested by rinsing off cells and cell products with $3.0 \mathrm{ml}$ of $0.01 \mathrm{M}$ sodium phosphate buffer, $\mathrm{pH} 7.2$. The suspension was then centrifuged at $9550 \times g$ for $5 \mathrm{~min}$. The supernatants were collected and either centrifuged a second time or filtered using a $0.45 \mu \mathrm{m}$ pore diameter membrane filter to remove cells.

Cell-free culture supernatants were also used as a source of bacterial ECP. Flasks containing $125 \mathrm{ml}$ of TYES broth were inoculated with $0.5 \mathrm{ml}$ of broth culture. Aliquots of broth culture were centrifuged and filtered to remove cells as described for DMO-ECP. Negative controls were prepared for the 2 types of ECP preparations by using sterile TYES broth as the inoculum. The ECP were stored at $-70^{\circ} \mathrm{C}$.

Colorimetric quantitative protease assay. Quantitative protease assays using azocasein (Sigma) as substrate were performed based on the method of Sarath et al. (1989). A $2 \%(w / v)$ solution of azocasein in $0.1 \mathrm{M}$ Tris- $\mathrm{HCl}_{1} \mathrm{pH}$ 7.2, was used as substrate. Reagent blanks were prepared by adding Tris buffer and negative control ECP. The reaction mixture was incubated in a $25^{\circ} \mathrm{C}$ water bath for $4 \mathrm{~h}$. Intensity of the orange color was measured as optical density (OD) in a Spectronic-20 (Bausch and Lomb) at $440 \mathrm{~nm}$. The assay was performed using triplicate samples. One OD unit of proteolytic activity was defined as an increase in $O D$ of 0.001 at $440 \mathrm{~nm}$ under the conditions of the assay. A reference standard curve for trypsin (Sigma, catalog no. $\mathrm{T}$ 8253) with 10.2,102, 1020 and 10200 units trypsin $\mathrm{ml}^{-1}$ in $0.1 \mathrm{M}$ Tris-HCl, $\mathrm{pH} 7.2$, was included with each assay and a linear relationship existed $(\mathrm{R}=0.99)$ between $\mathrm{OD}$ units and the log of trypsin concentration.

Substrate SDS-PAGE. Analysis of proteases by substrate gel electrophoresis was performed by the methods of Heussen \& Dowdle (1980) with modifica- 
tions. Electrophoresis was conducted as described by Laemmli (1970); however, gelatin (Difco) or casein (Sigma) was added to $12 \%$ resolving gels at $0.01 \%$ from $1 \%$ stocks prepared in water. Three volumes of sample were combined with one volume of sample buffer consisting of $10 \%$ sodium dodecyl sulphate (SDS), $8 \%$ of a $0.5 \mathrm{mg} \mathrm{ml}^{-1}$ bromophenol blue stock solution, and $30 \%$ glycerol dissolved in $0.5 \mathrm{M}$ Tris- $\mathrm{HCl}$, pH 6.8. Bacterial ECP samples were not boiled. Electrophoresis was conducted on a Bio-Rad model 220 vertical slab gel electrophoresis cell overnight at $4^{\circ} \mathrm{C}$ using a constant current of $7.5 \mathrm{~mA}$ per gel. After electrophoresis, the remaining steps were conducted at room temperature. The gels were incubated for $1 \mathrm{~h}$ in a $2.5 \%$ solution of Triton $\mathrm{X}-100$ which was changed once after $30 \mathrm{~min}$. The gels were then incubated for $4 \mathrm{~h}$ in $0.1 \mathrm{M}$ glycine- $\mathrm{NaOH}, \mathrm{pH} 8.3$, which was changed once after $2 \mathrm{~h}$. Gels were then fixed and stained with Coomassie Brilliant Blue. Proteases were separated based on their different electrophoretic mobilities and detected based on their ability to digest the protein substrates incorporated into the acrylamide gels. The presence of a protease was indicated by a band of clearing in the blue color of the stained substrate background. The relative migration distance of the proteases was compared with standard molecular weight markers to yield an apparent molecular weight (AMW) determination; however, this method does not provide accurate molecular weight estimation (Heussen \& Dowdle 1980).

Protease inhibition. The effect of protease inhibitors and divalent cations was examined based on Norqvist et al. (1990). A solution containing an inhibitor or inhibitor plus metal ions, or the solvent without additives, was added $(1: 100 \mathrm{v} / \mathrm{v})$ to the protease sample (a trypsin solution or a sample of DMO-ECP) which initially produced comparable proteolytic activity. The DMO-ECP of reference isolate Flexibacter columnaris 2.1 (246 OD units) was harvested after $2 \mathrm{~d}$ of culture and stored at $-70^{\circ} \mathrm{C}$ prior to use. A trypsin sample of
102 units $\mathrm{ml}^{-1}$ (271 OD units) was used for comparison. The mixture was incubated at room temperature for 5 min prior to assaying for protease activity. Stock solutions $(100 \times$ conc.) of $0.1 \mathrm{M}$ phenyl methyl sulfonyl fluoride (PMSF) and $0.1 \mathrm{M}$ 1,10-phenanthroline (OPA) were prepared in 2-propanol. Stock solutions (100 $\times$ conc.) of $1 \mathrm{M}$ EDTA, $0.2 \mathrm{M} \mathrm{ZnCl}, 0.2 \mathrm{M} \mathrm{CaCl}_{2}$, and $0.2 \mathrm{M} \mathrm{MgCl}_{2}$ were prepared in water. The effect of protease inhibitors on substrate SDS-PAGE was examined by adding either PMSF or EDTA, final concentrations 1 and $10 \mathrm{mM}$ respectively, to the Triton $\mathrm{X}$ 100 and glycine solutions.

Degradation of protein substrates. Substrates were incorporated into agar medium as follows: gelatin $0.6 \%$, casein $0.5 \%$, hemoglobin $0.1 \%$, fibrinogen $0.1 \%$, or elastin $0.05 \%$, based on the methods of Shotts et al. (1985) but modified so that the basal medium was TYES. Flexibacter columnaris isolates were inoculated by stabbing the media, and degradation of the substrate was observed as a zone of clearing surrounding the bacterial growth within $5 \mathrm{~d}$ after inoculation.

\section{RESULTS}

\section{Variability in proteases as a factor of culture age}

In order to identify proteases produced by Flexibacter columnaris and determine if the type of proteases produced varied with the age of the culture, DMO-ECP of reference isolate Flexibacter columnaris 2.1 was harvested immediately after inoculation of the plated medium and then daily for $8 \mathrm{~d}$. When representative preparations were analyzed using gelatin SDS-PAGE, bands of clearing indicated that proteases with AMWs of $47,40,34$, and $32 \mathrm{kD}$ were present by the end of Day 1 (Fig. 1). No additional protease bands were found on subsequent days. The protease profiles changed only slightly with time. After Day 1 the protease of AMW $40 \mathrm{kD}$ was seen only faintly; following this, it increased
Fig. 1. Gelatin SDS-PAGE analysis of Flexibacter columnaris 2.1 DMO-ECP preparations. MW: molecular weight standards (values in $\mathrm{kD}$ ). Numbers above lanes indicate time (in $d$ post inoculation) at which DMO-ECP was collected, with ' 0 ' indicating DMOECP collected immediately after inoculation. Bands of clearing indicate the presence of proteases

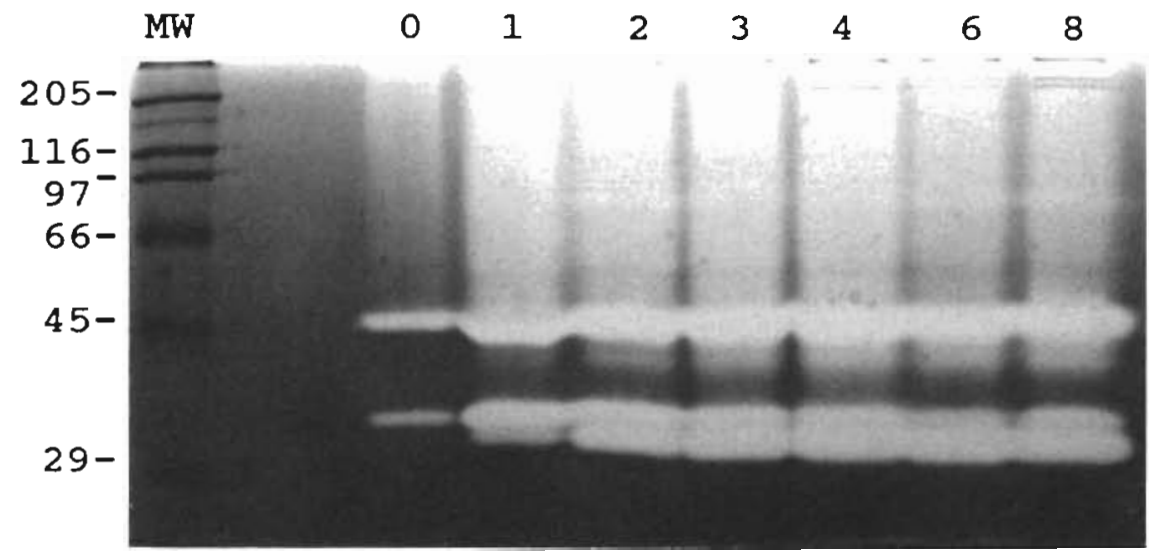




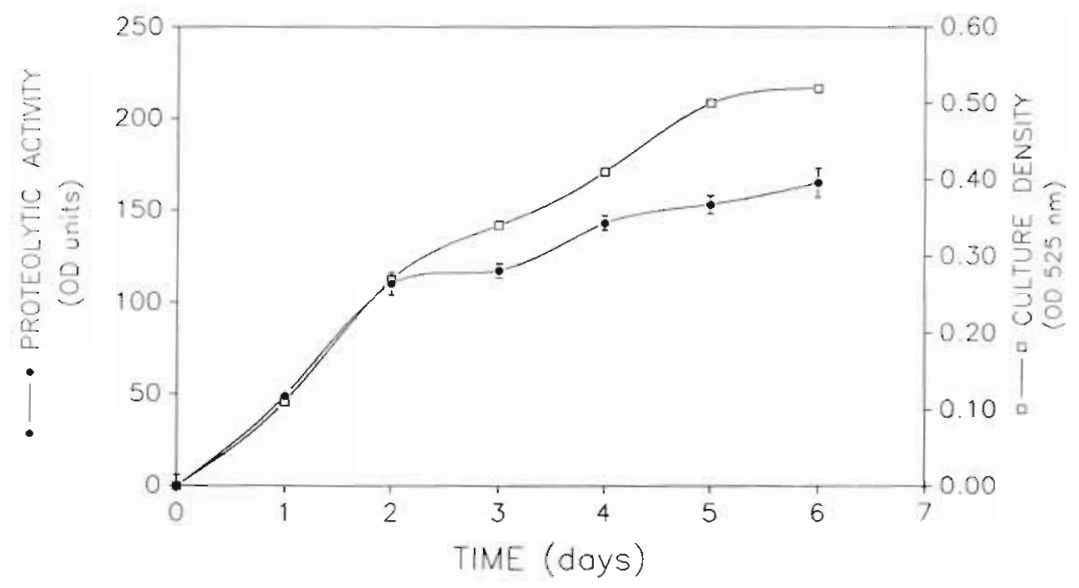

Fig. 2. Proteolytic activity of cell-free culture supernatants of Flexibacter columnaris 2.1 as a function of culture age. TYES broth culture of isolate 2.1 was collected immediately after inoculation and then daily for $6 \mathrm{~d}$. Culture density was determined on a Spectronic-20, after which cells were removed and proteolytic activity determined by quantitative protease assay with azocasein. Proteolytic activity values indicate the mean of assays performed in triplicate \pm standard deviation. Results shown are representative of 3 experiments

in intensity. The relative intensities of the proteases of AMWs 34 and $32 \mathrm{kD}$ also varied over time. Similar results were seen when the DMO-ECP was analyzed using casein SDS-PAGE. One difference noted was that the protease of AMW $40 \mathrm{kD}$ produced only a faint band of clearing on the casein gels.

When cell-free culture supernatants rather than DMO-ECP were analyzed, protease profiles also showed little variability from Day 1 through the end of the experiment on Day 6. These profiles differed from those produced by DMO-ECP in that the band of clearing associated with the protease of AMW $32 \mathrm{kD}$ was undetectable until Days 5 and 6, when it became faintly discernible. Negative control preparations from dialysis membrane overlays and sterile TYES broth produced no bands of clearing on substrate SDS-PAGE.

Quantitative determinations of proteolytic activity associated with a broth culture of reference isolate Flexibacter columnaris 2.1, sampled daily over a $6 \mathrm{~d}$ period, revealed increased proteolytic activity that closely paralleled the increase in optical density of the culture (Fig. 2). Proteolytic activity rose sharply during the first $2 \mathrm{~d}$ to $110 \mathrm{OD}$ units and then more gradually for the remainder of the experiment, reaching 165 OD units (activity comparable to 31.8 units trypsin $\mathrm{ml}^{-1}$ ) by Day 6. In a separate experiment, proteolytic activity associated with DMO-ECP preparations reached maximum or near maximum levels (ca 230 OD units, comparable to 49.4 units trypsin $\mathrm{ml}^{-1}$ ) by the second day of culture and then remained close to those levels until the last time point examined on the eighth day of culture (data not shown).

\section{Variability in proteases among Flexibacter colum- naris isolates}

We compared proteases of isolate 2.1 DMO-ECP with the proteases in DMO-ECP of 12 additional Flexibacter columnaris isolates. The DMO-ECP of all the isolates were collected after $4 \mathrm{~d}$ in culture because the previously conducted time-course experiment indicated that at this time proteolytic activity was at near maximum and that all 4 protease bands were present on substrate SDS-PAGE. The F. columnaris isolates chosen were from a variety of sources including coldwater and
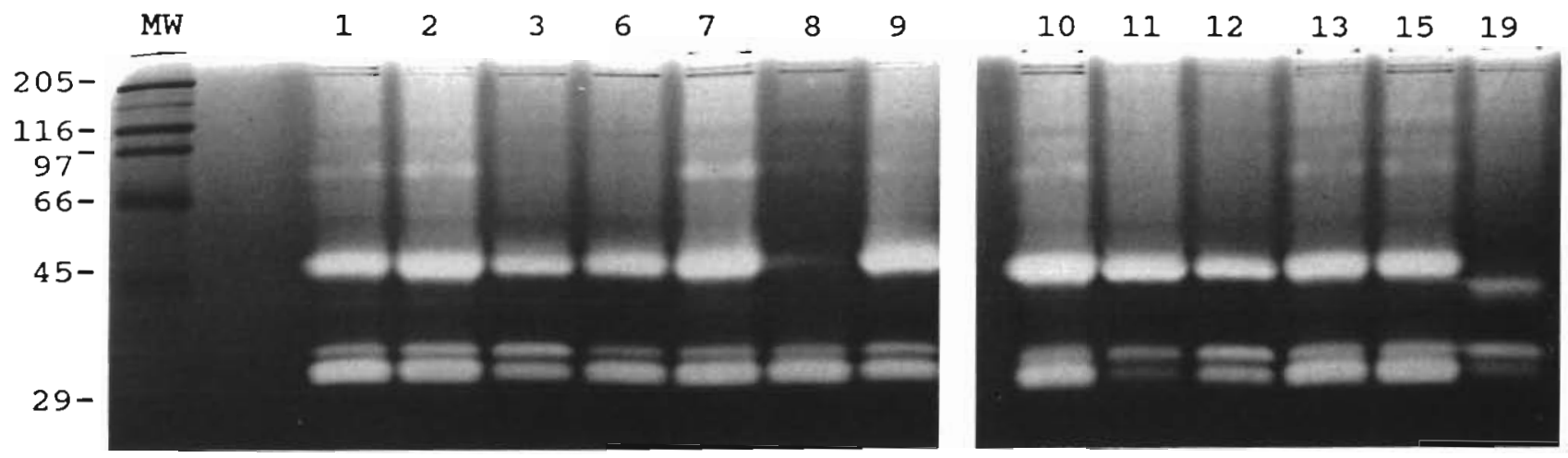

Fig. 3. Casein SDS-PAGE analysis comparing DMO-ECP preparations from 13 Flexibacter columnaris isolates. MW: molecular weight standards (values in $\mathrm{kD}$ ). Lanes are labelled with isolate numbers, without the '2.' prefix shown in Table 1 
Fig. 4. Gelatin SDS-PAGE analysis comparing DMO-ECP preparations of 8 different gliding bacteria. MW: molecular weight standards (values in kD). Lanes: (A) Flexibacter columnaris 2.1; (B) Flexibacter psychrophilus NCMB 1947; (C) Cytophaga sp. SF87-36; (D) Cytophaga sp. C1B2; (E) Cytophaga sp. WB1B1; (F) Cytophaga succinicans; (G) $C y-$ tophaga johnsonae; (H) Flexibacter aurantiacus ssp. excathedrus

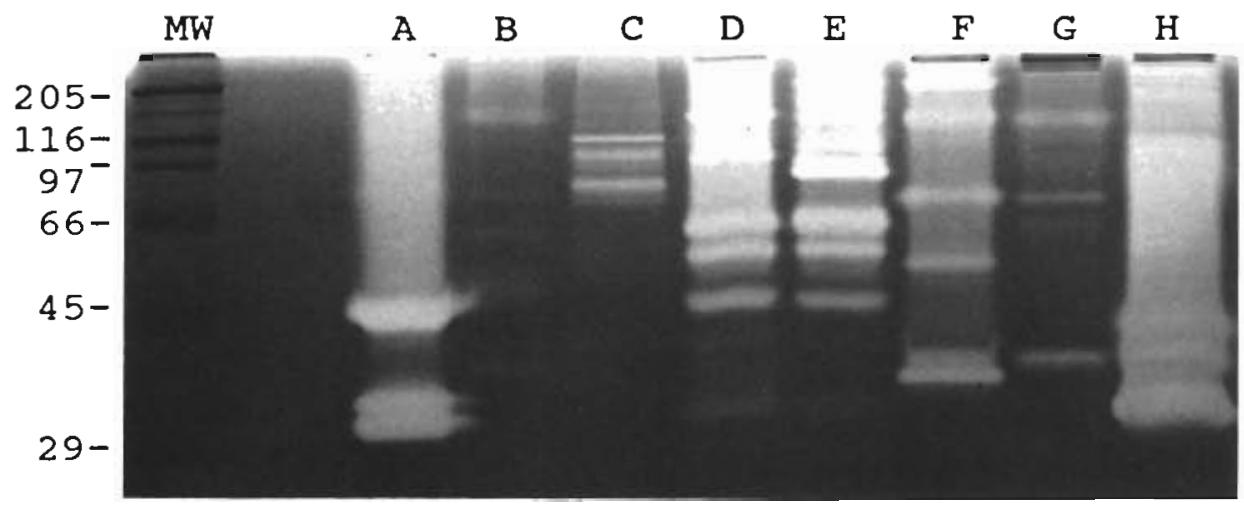

warmwater fishes and included isolates from the Pacific Northwest, the southern USA and an isolate from Japan. The protease profiles of the $13 \mathrm{~F}$. columnaris isolates showed uniformity (Fig. 3). Two variations from the typical profile were that isolate 2.8 was deficient in the production of the protease of AMW $47 \mathrm{kD}$ and that isolate 2.19, from diseased channel catfish in Louisiana, had a protease with AMW $44 \mathrm{kD}$ rather than $47 \mathrm{kD}$. The protease profile of isolate $F$. columnaris 2.19 also displayed a less intense band at AMW $40 \mathrm{kD}$.

Examination of the ability of the Flexibacter columnaris isolates to degrade a number of protein substrates also suggested uniformity in the proteolytic activity of these organisms. All 13 of the $F$. columnaris isolates tested degraded gelatin, casein, hemoglobin, fibrinogen, and elastin.

\section{Comparison of protease profiles of gliding bacteria}

When the DMO-ECP preparations of a number of different gliding bacteria species, collected after $4 \mathrm{~d}$ in culture, were examined by gelatin SDS-PAGE and compared with Flexibacter columnaris 2.1 DMO-ECP (Fig. 4) all the bacteria produced bands of clearing, but the profiles were markedly different from that associated with $F$. columnaris isolates. The 2 isolates from Pacific oyster showed bands with electrophoretic mobilities similar to those for the F. columnaris isolate; however, unlike the $F$. columnaris proteases these bands showed almost no activity when analyzed by casein SDS-PAGE. The oyster isolates also produced several other bands not present in the $F$. columnanis profile. Flexibacter aurantiacus ssp. excathedrus produced a band with electrophoretic mobility similar to that for the $F$. columnaris proteases of AMW 34 and $32 \mathrm{kD}$ but apparently lacked a protease of AMW $47 \mathrm{kD}$. A band was detected, with AMW of $155 \mathrm{kD}$, that was common to $F$. psychrophilus and the 2 oyster Cytophaga species, $C$. succinicans, and C. johnsonae; however, bands that distinguished the pathogenic from the non-pathogenic strains were not observed.

\section{Effects of protease inhibitors}

When Flexibacter columnaris 2.1 DMO-ECP was treated with $10 \mathrm{mM}$ EDTA, its proteolytic activity was inhibited to $6.6 \%$ of the non-treated control level, whereas $1 \mathrm{mM}$ PMSF had only a slight inhibitory effect, reducing proteolytic activity to $83.3 \%$ of control (Fig.5). The effects of these inhibitors were reversed when trypsin was tested; EDTA did not have a pronounced effect while PMSF lowered activity to $17.1 \%$ of control. Similarly, $10 \mathrm{mM}$ EDTA inhibited proteolytic activity when 2.1 DMO-ECP was analyzed by substrate SDS-PAGE but $1 \mathrm{mM}$ PMSF had no visible effect (data not shownl. Although treatment with $1 \mathrm{mM}$ OPA had no effect on trypsin, it reduced the proteolytic activity

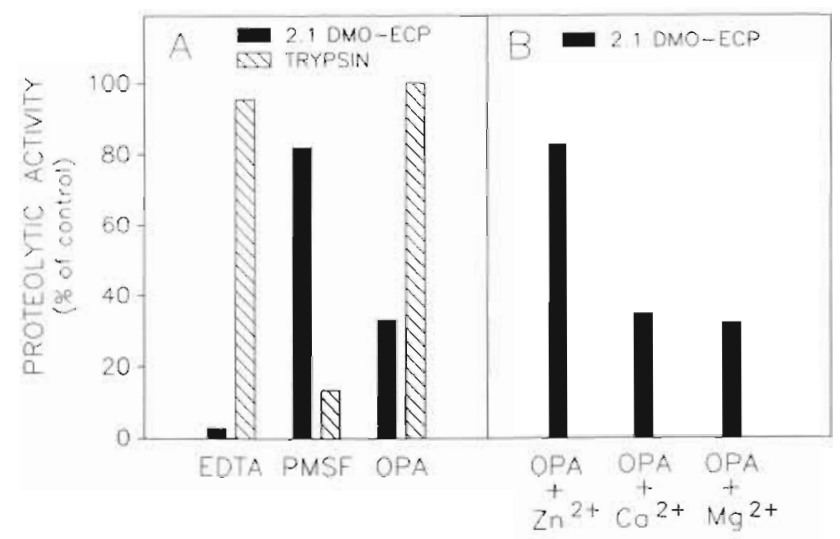

Fig. 5. Effects of protease inhibitors and the role of divalent cations on the proteolytic activity of Flexibacter columnaris 2.1 DMO-ECP. (A) Comparison of the effects of $10 \mathrm{mM}$ ethylene diamine tetraacetic acid (EDTA), $1 \mathrm{mM}$ phenyl methyl sulfonyl fluoride (PMSF) or $1 \mathrm{mM}$ 1,10-phenanthroline (OPA) on F. columnaris $2.1 \mathrm{DMO}-\mathrm{ECP}$ and trypsin. (B) Effects of $\mathrm{ZnCl}_{2}$, $\mathrm{CaCl}_{2}$, or $\mathrm{MgCl}_{2}(2 \mathrm{mM})$ on the proteolytic activity of OPA. $(1 \mathrm{mM})$ treated $F$. columnaris $2.1 \mathrm{DMO}-\mathrm{ECP}$ 
of 2.1 DMO-ECP to $33.3 \%$ of control levels (Fig. 5). Proteolytic activity of OPA-treated 2.1 DMO-ECP could be restored to $83.1 \%$ of control levels by the addition of $\mathrm{Zn}^{2+}$, but $\mathrm{Ca}^{2+}$ and $\mathrm{Mg}^{2+}$ did not restore proteolytic activity.

\section{DISCUSSION}

The Flexibacter columnaris strain 2.1, which was used as a reference strain, was found to produce extracellular proteases which migrated to AMWs of 47 , 40,34 , and $32 \mathrm{kD}$ when DMO-ECP was analyzed by substrate SDS-PAGE with gelatin. The $40 \mathrm{kD}$ band was faintly detectable when casein was used as substrate. It was not clear whether the $40 \mathrm{kD}$ band was not active against casein or if a higher concentration of the protease was needed in order to digest casein. Protease profiles observed when cell-free culture supernatants were analyzed were very similar to those produced using DMO-ECP; however, the protease of AMW $32 \mathrm{kD}$ was much less prominent. Although the 4 molecules each have proteolytic activity, we do not know if they represent 4 distinct enzymes. Some of the bands may represent sub-units, degradation products, or alternate forms of the same enzyme and may bear the same active site.

Culture age did not appear to be an important factor influencing the type of proteases produced. The 4 major extracellular proteases from DMO-ECP preparations were apparent on gelatin SDS-PAGE by the end of the first day of culture, and although the relative intensities of the bands changed, no additional protease types were observed throughout the course of the $8 \mathrm{~d}$ experiment. The material collected immediately after inoculation showed the presence of some protease material that was present in the inoculum. This material was not detectable by the quantitative assay with azocasein, but was detectable by the substrate SDS-PAGE technique. No proteolytic activity was found associated with negative control preparations of DMO-ECP or cell-free culture supernatants when they were analyzed by substrate SDS-PAGE.

When the quantitative assay with azocasein was used to examine protease activity as a factor of culture age, we found that protease activity rose sharply during the first $2 \mathrm{~d}$ in culture. In broth cultures, the protease concentrations continued to increase over the $6 \mathrm{~d}$ period, but more gradually. On TYES agar plates, the proteases were at close to maximum concentrations by the second day and then remained at similar levels for as long as $8 \mathrm{~d}$. Because only cell-free preparations were used in the analyses of proteolytic activity, the observation of sharply increasing protease activity during logarithmic growth phase indicates that the proteases were being actively secreted rather than being released from lysing cells.

Using the quantitative azocasein assay to study the effects of protease inhibitors, we found that PMSF, which is an inhibitor of serine proteases such as trypsin, produced only slight inhibition of the protease activity of Flexibacter columnaris 2.1 DMO-ECP. The metalloprotease inhibitors, EDTA and OPA, produced a more pronounced, although not complete inhibition. When substrate SDS-PAGE was conducted in the presence of the inhibitors, all 4 protease bands were inhibited by EDTA, but PMSF had no observable effect. These results indicate that a major component of the proteolytic activity, and the protease activity visualized by substrate SDS-PAGE, was associated with metalloproteases but suggests that another class of protease may be also present in the crude DMO-ECP. Results of experiments with divalent cations demonstrated that the metalloprotease component was dependent on $\mathrm{Zn}^{2+}$ for its activity.

Our examination of the extracellular proteases produced by the 13 Flexibacter columnaris isolates using casein SDS-PAGE of DMO-ECP preparations indicated a uniformity in the protease profiles. This uniformity was observed in isolates from warmwater as well as coldwater fish and also those representing a variety of geographic sources. Notably, an isolate from Louisiana, taken from diseased channel catfish, varied in the electrophoretic mobility of one of the protease bands. Further study is needed to determine if this is a characteristic which is typical of $F$. columnaris causing disease in farmed channel catfish in the southern USA. The other variant that occurred was found to be deficient in the production of the protease of AMW $47 \mathrm{kD}$.

The uniformity in protease profiles observed among the Flexibacter columnaris isolates contrasted sharply with the heterogeneity in the profiles of the other gliding bacteria studied and permitted the F. columnaris isolates to be differentiated from them. However, based on the electrophoretic mobility of the protease bands, it was not possible to differentiate the nonpathogens (Cytophaga succinicans, C. johnsonae, and $F$. aurantiacus ssp. excathedrus) from the pathogenic isolates (all of the other isolates tested). It is possible that minor structural differences could cause changes in electrophoretic mobility (and substrate specificity) of otherwise very similar proteases produced by different species. For example, Nottage \& Birkbeck (1987) studied 7 isolates representing 4 marine Vibrio spp. that were pathogens of either fish or shellfish: $V$ ordalii, $V$. anguillarum, $V$. alginolyticus, and $V$. tubiashi. The isolates fell into 3 groups based on differences in their protease profiles on substrate SDSPAGE; however, antiserum prepared against purified $V$ alginolyticus protease neutralized the proteases pro- 
duced by all 7 Vibrio isolates, and, on immunodiffusion, $V$ alginolyticus protease also gave a reaction of partial antigenic identity with the proteases of each of the Vibrio isolates

The uniformity found among the Flexibacter columnaris proteases was consistent with the findings of Bernardet \& Grimont (1989) and Starliper et al. (1988), who reported that $F$. columnaris represents a distinct species with relatively little genetic diversity. Our results indicate that characterization of $F$. columnaris extracellular proteases can proceed with representative reference isolates and should yield information applicable to the species.

Acknowledgements. The authors thank the individuals who contributed bacterial isolates and R. A. Holt and J. L. Fryer for helpful suggestions during the work and mansucript preparation. This publication is the result of research sponsored by Oregon Sea Grant with funds from the National Oceanic and Atmospheric Administration, Department of Commerce, under grant no. NA 89AA-D-SG108 (project no. R/FSD-14). Oregon Agricultural Experiment Station Technical Paper no. 9488 .

\section{LITERATURE CITED}

Allan, B. J., Stevenson, R. M. W. (1981). Extracellular virulence factors of Aeromonas hydrophila in fish infections. Can. J. Microbiol. 27: 1114-1122

Amin N. E., Aboallah, I. S., Fäisal, M., Easa, M. El-S., Alaway, T., Alyan, S. A. (1988). Columnaris infection among cultured Nile tilapia Oreochromis niloticus. Antonie van Leeuwenhoek 54: 509-520

Anacker, R. L., Ordal, E. J. (1959). Studies on the myxobacterium Chondrococcus columnaris I. Serological typing. J. Bacteriol. 78: 25-32

Azghani, A. O., Connelly, J. C., Peterson, B. T., Gray, L. D., Collins, M. L., Johnson, A. R. (1990). Effects of Pseudomonas aeruginosa elastase on alveolar epithelial permeability in guinea pigs. Infection Immunity 58 $433-438$

Becker, C. D., Fujihara, M. P. (1978). The bacterial pathogen Flexibacter columnaris and its epizootiology among Columbia River fish. Monograph No. 2. American Fisheries Society, Washington, D.C.

Bejarno, P. A., Langeveld, J. P. M., Hudson, B. G., Noelken M. E. (1989). Degradation of basement membranes by Pseudomonas aeruginosa elastase. Infection Immunity 57 3783-3787

Bernardet, J. F. (1989). 'Flexibacter columnaris': first description in France and comparison with bacterial strains from other origins. Dis. aquat. Org. 6: 37-44

Bernardet, J. F., Grimont, P. A. D. (1989). Deoxyribonucleic acid relatedness and phenotypic characterization of Flexibacter columnaris sp. nov., nom. rev., Flexibacter psychrophilus sp. nov., nom. rev., and Flexibacter maritimus Wakabayashi, Hikida, and Masumura 1986. Int. J. system. Bacteriol. 39: 346-354

Bootsma, R., Clerx, J. P. M. (1976). Columnaris disease of cultured carp Cyprinus carpio L. characterization of the causative agent. Aquaculture $7: 371-384$

Chabot, D. J., Thune, R. L. (1991). Proteases of the Aeromonas hydrophila complex: identification, characterization and relation to virulence in channel catfish. Ictalurus punctatus (Rafinesque). J. Fish Dis. 14: 171-183

Davis, H. S. (1922). A new bacterial disease of fresh-water fishes. Bull. U.S. Bur Fish. 38: 261-280

Davis, H. S. (1947). Cytophaga columnaris as a cause of fish epidemics. Trans. Am. Fish. Soc. 77. 102-104

Dungan, C. F, Elston, R. A., Schiewe, M. H. (1989). Evidence for colonization and destruction of hinge ligaments in cultured juvenile Pacific oysters (Crassostrea gigas) by cytophaga-like bacteria. Appl. environ. Microbiol. 55: $1128-1135$

Farkas, J., Olah, J. (1986). Gill necrosis - a complex disease of carp. Aquaculture 58: 17-26

Fish, F. F., Rucker, R. R. (1943). Columnaris as a disease of cold-water fishes. Trans. Am. Fish. Soc. 73: 32-36

Fyfe, L., Coleman, G., Munro, A. L. S. (1987). Identification of major common extracellular proteins secreted by Aeromonas salmonicida strains isolated from diseased fish. Appl. environ. Microbiol. 53: 722-726

Hastings, T S., Ellis, A. E. (1985). Differences in the production of haemolytic and proteolytic activities by various isolates of Aeromonas salmonicida. In: Ellis, A. E. (ed.) Fish and shellfish pathology. Academic Press, London, p. 69-77

Heussen, C., Dowdle, E. B. (1980). Electrophoretic analysis of plasminogen activators in polyacrylamide gels containing sodium dodecyl sulfate and copolymerized substrates. Analyt. Biochem. 102: 196-202

Holder, I. A. (ed.) (1985). Bacterial enzymes and virulence, CRC Press, Boca Raton, FL

Holt, R. A. (1988). Cytophaga psychrophila, the causative agent of bacterial cold-water disease in salmonid fish. Ph.D. dissertation. Oregon State University, Corvallis

Kanemorl, Y., Nakai, T., Muroga, K. (1987). The role of extracellular protease produced by Vibrio anguillarum. Fish Path. 22: 153-158

Kent, M. L., Dungan, C. F., Elston, R. A., Holt, R. A. (1988). Cytophaga sp. (Cytophagales) infection in seawater penreared Atlantic salmon Salmo salar. Dis. aquat. Org. 4: $173-179$

Laemmli, U. K. (1970). Cleavage of structural proteins during the assembly of the head of the bacteriophage T4. Nature, Lond. 277: 680-685

Nieto, T P., Ellis, A. E. (1991). Heterogeneity of extracellular proteases produced by different isolates of Aeromonas hydrophila and A. sobria pathogenic for fish. J. Fish Dis. 14: 229-235

Norqvist, A., Norrman, B., Wolf-Watz, H. (1990). Identification and characterization of a zinc metalloprotease associated with invasion by the fish pathogen Vibrio anguillarum. Infection Immunity 58: 3731-3736

Nottage, A. S., Birkbeck, T H. (1987). Production of proteinase during experimental infection of Ostrea edulis L. larvae with Vibrio alginolyticus NCMB 1339 and the antigenic relationship between proteinases produced by marine vibrios pathogenic for fish and shellfish. J. Fish Dis. 10: $265-273$

Pacha, R. E., Ordal, E. J. (1967). Histopathology of experimental columnaris disease in young salmon. J. comp. Pathol. 77: 419-423

Pacha, R. E., Porter, S. (1968). Characteristics of myxobacteria isolated from the surface of freshwater fish. Appl. Microbiol. 16: 1901-1906

Rhodes, J. C., Amlung, T. W., Miller, M. S. (1990). Isolation and characterization of an elastinolytic proteinase from Aspergillus flavus. Infection Immunity 58: 2529-2534

Rockey, D. D., Fryer, J. L., Rohovec, J. S. (1988). Separation 
and in vivo analysis of two extracellular proteases and the T-hemolysin from Aeromonas salmonicida. Dis. aquat. Org. 5: 197-204

Sarath, G., de la Motte, R. S., Wagner, F. W. (1989). Protease assay methods. In: Benyon, R. J., Bond, J. J. (eds.) Proteolytic enzymes: a practical approach. IRL Press, Oxford, p. 25-55

Shotts, E. B., Hsu, T C., Waltman, W. D. (1985). Extracellular proteolytic activity of Aeromonas hydrophila complex. Fish Path. 20: $167-172$

Song, Y L., Fryer, J. L., Rohovec, J. S. (1988). Comparison of gliding bacteria isolated from fish in North America and other areas of the Pacific Rim. Fish Path. 23: 197-202

Starliper, C. E., Shotts, E. B., Hsu, T., Schill, W. B. (1988).

Responsible Subject Editor: $T$ Evelyn, Nanaimo, B. C., Canada
Genetic relatedness of some Gram-negative yellow pigmented bacteria from fishes and aquatic environments. Microbios 56: 181-198

Wakabayashi, H., Kira, K., Egusa, S. (1970). Studies on columnaris disease of pond-cultured eels. I. Characteristics and pathogenicity of Chondrococcus columnaris isolated from pond cultured eels. Bull. Jap. Soc. scient. Fish. 36: $147-153$

Wobeser, G, Atton, F. M. (1973). An outbreak of columnaris disease in white suckers (Catostomus commersoni) in Saskatchewan. J. Fish. Res. Bd Can. 30: 681-683

Wood, J. W (1974). Diseases of Pacific salmon - their prevention and treatment. State of Washington, Dept of Fisheries, Hatchery Division, Olympia, WA

Manuscript first received: January 24, 1991 Revised version accepted: October 11, 1991 